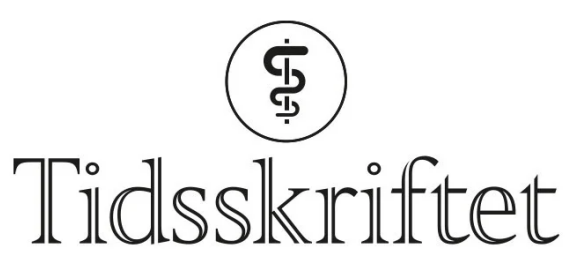

DEN NORSKE LEGEFORENING

\title{
Den norske Florence Nightingale
}

\section{ANMELDELSER}

RAGNAR STIEN

Oslo

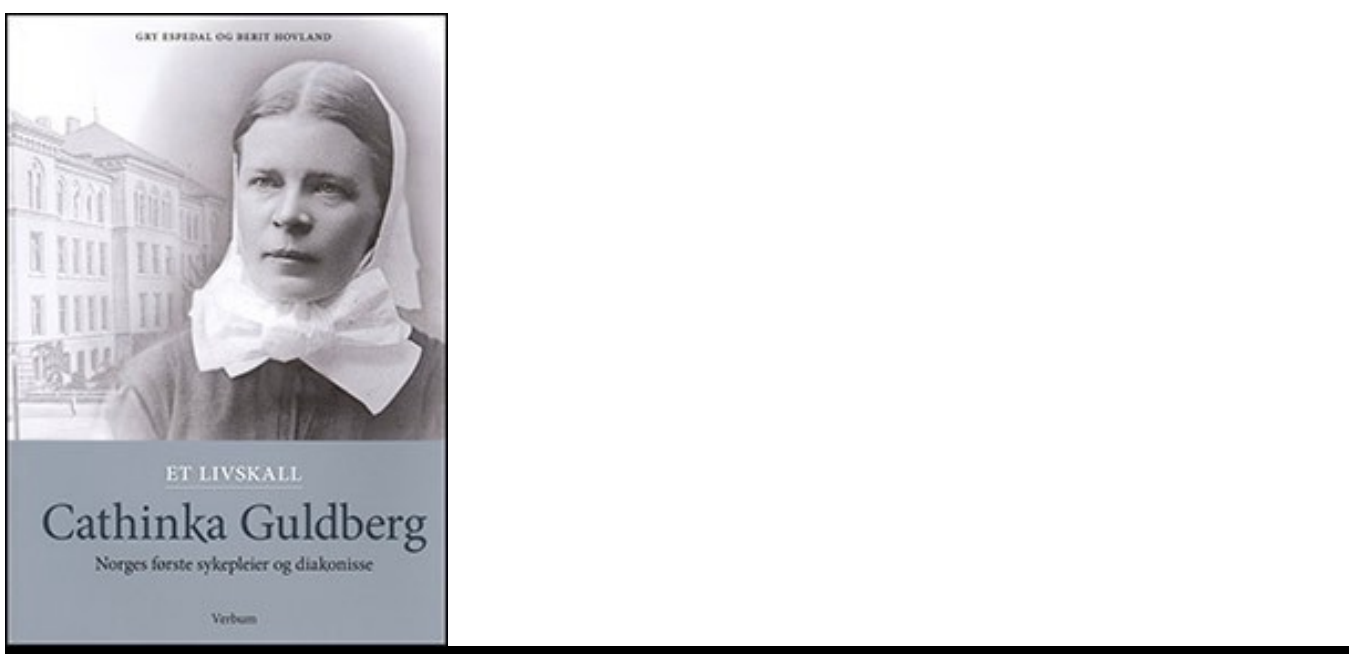

Espedal, Gry

Hovland, Berit

Et livskall - Cathinka Guldberg

Norges første sykepleier og diakonisse. 188 s, ill. Oslo: Verbum forlag, 2012. Pris NOK 348

ISBN 978-82-543-1216-2

Den kvinnen som på 18oo-tallet startet utdanningen av sykepleiere i Norge, Cathinka Guldberg, fortjener en biografi. Vårt samfunn anså den gangen utdanning av kvinner som bortkastet: De skulle bli gift, få barn og bli forsørget. De nye ekspanderende sykehusene hadde likevel behov for kvinner (selvfølgelig kvinner) som kunne pleie og stelle for de syke. Det var også ønskelig at de hadde et minimum av kunnskap om anatomi, sykdommer og deres behandling og at de var gudfryktige og ikke krevde for mye lønn. Biskopen i Oslo mente til og med at sykepleiere ikke burde få lønn fordi det korrumperte deres kall. 
En kvinne, samtidig med Camilla Collett og Aasta Hansteen, som fikk i gang et så banebrytende prosjekt som fagutdanning for sykepleiere, skulle man forvente var både viljesterk, idérik og en forkjemper for kvinners rettigheter. Slik blir hun ikke fremstilt i denne biografien. Hennes største initiativ var å dra fra sin borgerlige norske familie til Tyskland for å utdanne seg til diakonisse. Hun gjennomførte utdanningen, tjenestegjorde ved fronten i krigen mellom Østerrike og Preussen og senere ved et sykehus i Egypt. Så ble hun kalt hjem av Foreningen for indre Mission i Christiania for å starte utdanning av sykepleiere. Dette var en oppgave hun løste til alles tilfredshet. Likevel underordnet hun seg alltid Indremisjonens styre, aksepterte en mannlig forstander som sjef, og fremstår ikke som noen forkjemper for kvinners rett til utdanning.

Forfatterne fremstiller Cathinka Guldberg som en mild «mor» som kneler foran sofaen på sitt kontor og ber sin gud om økte ressurser og suksess for sine elever. Hennes mindre kjente stedfortreder, Rikke Nissen, blir beskrevet som den som har ideer, og som forfekter kvinnens rettigheter. I det hele er det forbløffende hvor vagt og forsiktig denne pioneren blir tegnet i boken. Forfatterne legger stor vekt på hennes kristne overbevisning, som tydeligvis gikk i nokså pietistisk retning. Kallstanken og inspirasjonen fra vekkelsen rundt Gisle Johnson blir understreket. Denne vektleggingen er kanskje ikke så overraskende når forfatterne er en sykehusprest og en pensjonert diakonisse.

Boken er lettlest og oversiktlig. Forfatterne putter inn korte beretninger om sentrale personer og samfunnsforholdene i Norge. Disse er trykt på sider med annen farge enn selve biografien. Noen illustrasjoner, vesentlig portretter, liver også opp fremstillingen. Et tillegg gir opplysninger om de viktigste personene som er nevnt. Dette registeret har ikke sidehenvisninger, noe som hadde vært en fordel. En litteratur- og kildeoversikt foreligger også. Det virker som om boken er skrevet for «menigheten» av sykepleiere som er utdannet ved Lovisenberg og Diakonissehuset. Likevel hadde biografien om Cathinka Guldberg fortjent et betydelig større publikum. I en velutdannet ressurssterk familie - her dukker både massevirkningsloven og akademiske kor opp - hadde jeg forventet en klarere og skarpere tegnet kvinneskikkelse. For dyktig og handlekraftig må vel Cathinka Guldberg ha vært?

Publisert: 9. april 2013. Tidsskr Nor Legeforen. DOI: 10.4045/tidsskr.13.0086 (C) Tidsskrift for Den norske legeforening 2023. Lastet ned fra tidsskriftet.no 26. april 2023. 